\title{
Impact of Environment and Ontogeny on Relative Fecundity and Egg Quality of Female Oysters (Crassostrea virginica) from Four Sites in Northern Chesapeake Bay
}

HL Glandon

AK Michaelis

et al

Kimberly S. Reece

Virginia Institute of Marine Science

et al

Follow this and additional works at: https://scholarworks.wm.edu/vimsarticles

Part of the Aquaculture and Fisheries Commons

\section{Recommended Citation}

Glandon, HL; Michaelis, AK; al, et; Reece, Kimberly S.; and al, et, "Impact of Environment and Ontogeny on Relative Fecundity and Egg Quality of Female Oysters (Crassostrea virginica) from Four Sites in Northern Chesapeake Bay" (2016). VIMS Articles. 1691.

https://scholarworks.wm.edu/vimsarticles/1691

This Article is brought to you for free and open access by the Virginia Institute of Marine Science at W\&M ScholarWorks. It has been accepted for inclusion in VIMS Articles by an authorized administrator of W\&M ScholarWorks. For more information, please contact scholarworks@wm.edu. 


\title{
Impact of Environment and Ontogeny on Relative Fecundity and Egg Quality of Female Oysters (Crassostrea virginica) from Four Sites in Northern Chesapeake Bay
}

\author{
HILLARY LANE GLANDON ${ }^{1, *, \dagger}$, ADRIANE K. MICHAELIS ${ }^{1}$, VINCENT A. POLITANO ${ }^{1, *}$, \\ STEPHANIE T. ALEXANDER ${ }^{2}$, EMILY A. VLAHOVICH ${ }^{2}$, KIMBERLY S. REECE ${ }^{3}$, \\ HEATHER N. KOOPMAN ${ }^{4}$, DONALD W. MERITT ${ }^{2}$, AND KENNEDY T. PAYNTER ${ }^{1,5}$ \\ ${ }^{1}$ University of Maryland, Department of Biology, College Park, Maryland 20742; ${ }^{2}$ University of \\ Maryland Center for Environmental Science, Horn Point Laboratory, Cambridge, Maryland 21613; \\ ${ }^{3}$ Virginia Institute of Marine Science, College of William and Mary, P. O. Box 1346, Gloucester Point, \\ Virginia 23062; ${ }^{4}$ University of North Carolina at Wilmington, Department of Biology and Marine \\ Biology, Wilmington, North Carolina 28403; and ${ }^{5}$ University of Maryland Center for Environmental \\ Science, Chesapeake Biological Laboratory, Solomons, Maryland 20688
}

\begin{abstract}
Resource allocation to reproduction is a primary physiological concern for individuals, and can vary with age, environment, or a combination of both factors. In this study we quantified the impact of environment and individual age on the reproductive output of female oysters Crassostrea virginica. We determined the relative fecundity, egg total lipid content, and overall and omega3/omega-6 ( $\omega 3 / \omega 6)$ fatty acid signatures (FAS) of eggs spawned by female oysters over a 2-year period $(n=32$ and $n=64)$. Variation was quantified spatially and ontogenetically by sampling young and old oyster populations from two rivers in Chesapeake Bay, totaling four collection sites. During Year 1, when oysters underwent oogenesis in different locations, overall and $\omega 3 / \omega 6$ egg FAS varied significantly by river, with no significant differences observed in the FAS of oysters by age in Year 1. In Year 2, when oysters from different sites underwent oogenesis in a single location, no significant differences in the overall egg FAS or $\omega 3 / \omega 6$ egg FAS by river or age
\end{abstract}

Received 3 March 2016; accepted 25 October 2016.

* To whom correspondence should be addressed. E-mail: hlane@umces. edu

$\dagger$ Current address: University of Maryland Center for Environmental Science, Chesapeake Biological Laboratory, Solomons, Maryland 20688.

$\ddagger$ Current address: Alaska Department of Fish and Game, 1255 West $8^{\text {th }}$ Street, Juneau, Alaska 99802. were observed. These findings suggest that oysters integrate environment into their reproductive output, but that time spent growing at a specific location (in this case, represented by oyster age) plays a relatively minor role in the biochemical composition of oyster eggs. These results have consequences for our understanding of how resources are allocated from the female oyster to eggs and, more generally, the impact of environment and ontogeny on reproductive physiology.

\section{Introduction}

Interactions between species and the environment are fundamental to the study of the ecology of systems. Foundational studies in ecology have examined how the environment may impact species number and diversity (Andrewartha and Birch, 1954; Lewis, 1964; Dayton, 1971). More recently, attention has focused on how the physiology of species may change in different environments (Dahlhoff et al., 2002; Porter et al., 2002; Kearney and Porter, 2009). For example, in habitats characterized by sharp environmental gradients, physiological parameters such as metabolic rate and tolerance to hypoxia are a primary determinant of species abundance and distribution (Phillips, 2007; Chown and Gaston, 2008). An understanding of the relationship between physiology and environment is critical in evaluating the factors that may influence abundance and 
distribution, and will lead to more informed decisions about species management and recovery.

Allocation of resources to growth and to reproduction are two primary physiological concerns of animals in nature (Brown et al., 2004). This resource allocation can change ontogenetically; many species invest energy towards somatic growth in the early life stages, then prioritize reproductive success, and, finally, can experience reproductive senescence later in life (Bell, 1984; Promislow, 1991; Philipp and Abele, 2010). This ontogenetic variation in the allocation of reproductive resources has implications for species that are managed by size or age. Often, regulations are aimed at allowing animals to remain in the wild until they have had the opportunity to successfully reproduce. While data on the minimum reproductive size are available for many species, the reproductive dynamics of older, larger individuals are less well understood. The goal of this study was to examine how environment and ontogeny may impact the quantity and quality of the reproductive output of an important species in the Chesapeake Bay ecosystem, the eastern oyster Crassostrea virginica.

The eastern oyster is an ideal species in which to examine the impacts of environment and ontogeny on resource allocation to reproductive output. Oysters are ubiquitous in many of the world's estuaries; they are reef-forming marine bivalves and are found from Central America through the Atlantic coast of North America. In Chesapeake Bay, the largest estuary in the continental United States, oysters form a critical component of the food web. They provide services to the ecosystem such as water filtration and habitat creation (Peterson et al., 2003; Rodney and Paynter, 2006; Grabowski and Peterson, 2007), and serve as important benthic-pelagic couplers (Newell et al., 2003; Porter et al., 2004). We also targeted the eastern oyster because the females produce new eggs each winter, and so their reproductive output may reflect environmental changes. Therefore, the water quality and phytoplankton species abundance and diversity that adult female oysters are exposed to may become a factor in the quality of reproductive output (Thompson et al., 1996).

The eastern oyster population in the Maryland portion of Chesapeake Bay was ideal for this study. As a result of a decades-long hatchery seeding program, the exact ages of many of the restored oyster populations throughout the state are known. This situation contrasts with other oyster populations throughout the continental U.S., where natural recruitment can make it difficult to know the exact age of any given oyster.

As synchronous broadcast spawners, eastern oyster females produce large numbers of eggs, increasing the likelihood that some eggs are fertilized (Kennedy, 1996). Female fecundity in $C$. virginica has been quantified as number of eggs produced, gonadal mass, or fertilization success (Cox and Mann, 1992; Choi et al., 1993; Kang et al., 2003; Royer et al., 2008). Factors influencing fecundity in females include age, salinity, and concentration and quality of the phytoplankton diet (Hofmann et al., 1992; Powell et al., 1992; Enriquez-Diaz, 2004). However, little information exists about changes in the quality of eggs produced by female $C$. virginica that are associated with oyster age or geospatial location where oogenesis occurred. Current data exist for a single age class (Kennedy et al., 1995) and as means across multiple ages (Gallager et al., 1986; Deslous-Paoli and Heral, 1988), leaving a dearth of knowledge regarding ontogenetic and geospatial variation in the quality of oyster eggs.

In this study we used the fatty acid signature (FAS) of the eggs as a proxy for egg quality; certain fatty acids play a critical role in the development of bivalve embryos. The relative proportions of the various fatty acids in each individual animal and/or tissue comprise its FAS, and differences in these proportions have been linked to important developmental milestones. In bivalves, specific omega-3 fatty acids (20:5n-3 and 22:6n-3) are considered especially important (Whyte et al., 1990, 1991; Helm et al., 1991; Marty et al., 1992). Changes in the proportions of these fatty acids in oyster eggs may have consequences for a developing embryo, although the magnitude of the difference required to elicit a response is not known. Fatty acid signature analysis has been widely used in the ecological literature to quantify the diets of marine animals from fish to phytoplankton to marine mammals (Watanabe, 1982; Bell et al., 1986; Sargent et al., 1987; Ahlgren et al., 1990). Fatty acids obtained from the diet are either directly incorporated into the animal tissue or further modified by the individual in vivo. Although changes in FAS have been linked to changes in diet (Kirsch et al., 1998; Raclot et al., 1998; Iverson et al., 2004), little work has been done to understand the effects of changes in diet on the quality of the reproductive output of individuals.

The goal of this study was to determine the influence of environment and ontogeny on the reproductive output of eastern oysters from northern Chesapeake Bay. Little is known about the influence of oyster age and geospatial location on fecundity measures. For the study, we identified two populations of adult oysters from two rivers. Each river has a different phytoplankton composition, according to Chesapeake Bay Program (CBP) data (Chesapeake Bay Program, 2013), a fact that could represent differences in available diet for the adult oysters. Our aim was to examine the effects of both oyster age and river (as a proxy for diet) on the reproductive output of adult female oysters. We hypothesized that both age and river would influence certain aspects of the reproductive output of adult female oysters. We predicted that 1) age would have a negative effect on the total number of eggs produced and 2) river would influence the fatty acid signatures of the oyster eggs. 


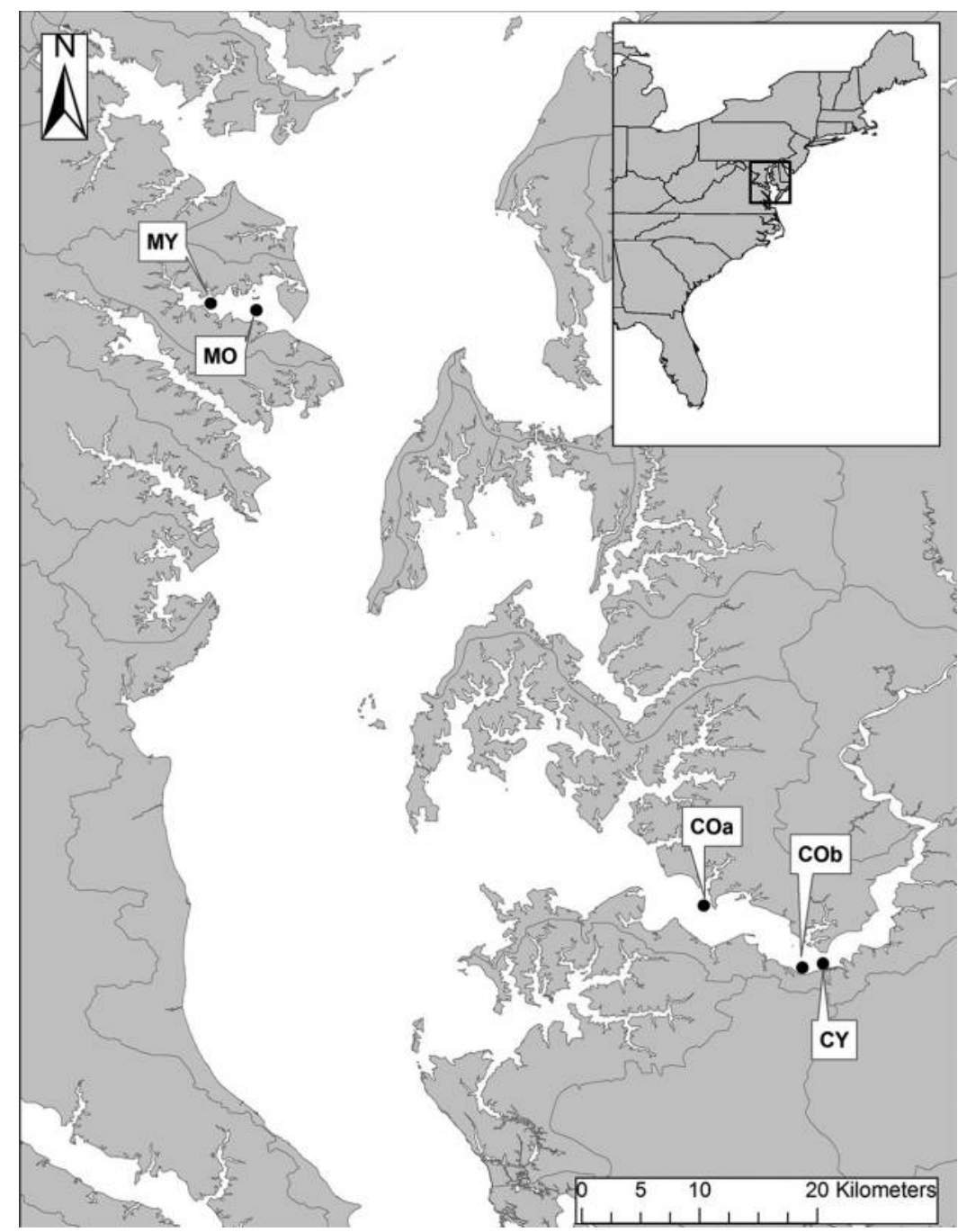

Figure 1. Adult oyster sampling locations in northern Chesapeake Bay. Each site was sampled in both 2010 and 2011 unless indicated on the map (i.e., $\mathrm{CO}_{\mathrm{a}}$ oysters were sampled in 2010 only, and $\mathrm{CO}_{\mathrm{b}}$ oysters were sampled in 2011 only). Inset, east coast of the United States, with area of interest boxed for geographical reference. C, Choptank River; M, Magothy River; O, old; Y, young; $\mathrm{CO}_{\mathrm{a}}$, Choptank old, Year 1; $\mathrm{CO}_{\mathrm{b}}$, Choptank old, Year 2; CY, Choptank young; MO, Magothy old; MY, Magothy young.

\section{Materials and Methods}

\section{Specimen collection}

To examine the effects of both environment and ontogeny on the reproductive output of eastern oysters in Chesapeake Bay, sampling locations that varied by oyster age and river source were identified. The two rivers selected are located on opposite sides of Chesapeake Bay (Fig. 1), and, as was mentioned above, differ in their phytoplankton composition (Chesapeake Bay Program, 2013). It is important to keep in mind that the CBP data are general to each river, and do not fully capture the variation in phytoplankton composition in these rivers on daily and seasonal scales. The data also may not fully represent what oysters are eating in the water column; previous work has reported that oysters may selectively feed (Newell and Jordan, 1983). However, the general differences observed in the CBP data show that oysters are exposed to different phytoplankton populations on the river scale. The sites within each river are relatively close by (no more than $10 \mathrm{~km}$ apart), but contain oysters that differ in age by at least 6 years. Therefore, samples from each site incorporated differences in both exposure time (oyster age) and food availability and quality. Since no replicate ages were sampled within rivers, the age comparisons may be confounded by river in this study.

For the 2010 spawn, 200 oysters were collected by divers from two sites each in the Choptank and Magothy Rivers on June 18, 2010. Animals were stored at the Horn Point 
Table 1

Oyster naming codes for age and location

\begin{tabular}{ccccc}
\hline \hline River & Site (oyster bar) & Age (2010) & Age (2011) & Code \\
\hline Magothy & Chest Neck & 4 & 5 & MY \\
Magothy & Dobbins & 11 & 12 & MO \\
Choptank & States Bank & 3 & 4 & CY \\
Choptank & Howell Point & 9 & N/A & CO $_{\mathrm{a}}$ \\
Choptank & Shoal Creek & N/A & 10 & CO $_{\mathrm{b}}$ \\
\hline
\end{tabular}

C, Choptank; M, Magothy; O, old; Y, young; $\mathrm{CO}_{\mathrm{a}}$, Choptank old Year $1 ; \mathrm{CO}_{\mathrm{b}}$, Choptank old Year 2.

Oyster Hatchery (HPOH) for 12 days prior to spawning to acclimate to the hatchery environment before assessment. This collection scheme allowed for analysis of the reproductive output of oysters of both age classes (young and old) and from both rivers. Young oysters (3-y-old) from the Choptank River ("Choptank Young;" CY) were from the States Bank oyster bar. Old oysters (9-y-old) from the Choptank River ("Choptank Old Year 1;" $\mathrm{CO}_{\mathrm{a}}$ ) were collected from Howell Point oyster bar. Young oysters (4-y-old) from the Magothy River ("Magothy Young;" MY) were collected from Chest Neck oyster bar, and old oysters (11-y-old) from the Magothy River ("Magothy Old;" MO) were from Dobbins oyster bar (Table 1, Fig. 1).

The 2010 spawn occurred on June 30, 2010. During this acclimation period, oysters were kept in running Choptank River water at a controlled temperature of $20{ }^{\circ} \mathrm{C}$ and at ambient salinity $(\sim 10 \mathrm{ppt})$. Oysters were not fed supplemental food during the acclimation period; the phytoplankton community already present in the Choptank River water was used to feed the oysters during this time. Although a strict light:dark cycle was not maintained during the acclimation period, lights were generally turned on during work hours (08:00-18:00) and turned off for the remainder of the day.

For the 2011 spawn, 200 oysters from each of the same 2 sites in the Magothy River, the Chest Neck and Dobbins oyster bars, were collected by divers on October 28, 2010. Another 200 oysters from the 2 sites in the Choptank River, the States Bank and Howell Point oyster bars, were collected on November 3, 2010. Because the density of adult oysters at Howell Point $\left(\mathrm{CO}_{\mathrm{a}}\right)$ was too low to support another 200-oyster collection, oysters from Shoal Creek oyster bar in the Choptank River ("Choptank Old Year 2;" $\mathrm{CO}_{\mathrm{b}}$ ) were collected instead. The Shoal Creek oyster bar is about $8 \mathrm{~km}$ from the Howell Point oyster bar, and contains a large population of oysters of the same age as those remaining on Howell Point. Oysters were kept for the winter in plastic floats in a boat basin that had water exchange with the Choptank River, so that oogenesis for oysters from all sites would occur in the same location. Oysters were moved into the hatchery 14 days prior to spawning to acclimate to the hatchery environment before sampling.

The 2011 spawn occurred on June 14 and 15, 2011. Table 1 defines the naming codes used in the text to refer to oysters of specific ages and locations.

\section{Spawning}

Staff of the Horn Point Oyster Hatchery conducted a ripeness analysis of two individuals from each site to estimate the population's readiness to spawn. A ripeness analysis involves shucking the oyster to examine the size and swollenness of the gonads, a metric that is related to the readiness of oysters to spawn (D. W. Meritt; pers. obs.). Once a portion of the animals appeared ready to spawn, spawning was initiated to avoid oysters spawning in the conditioning system. One hundred individual oysters from each site were placed on separate spawning tables (100 oysters per table; sex unknown until spawning) with running seawater at a temperature of $27{ }^{\circ} \mathrm{C}$ and salinity of 10 ppt, conditions similar to what the oysters would have experienced in upper Chesapeake Bay in summer. Since the goal of this study was to examine the eggs of females from different field locations and ages, the methods used to induce spawning were carefully chosen to mimic the conditions that females would have experienced in the field.

To stimulate spawning, the temperature was raised to $30{ }^{\circ} \mathrm{C}$ over the course of an hour, after which the animals were left at $30{ }^{\circ} \mathrm{C}$ for $1 \mathrm{~h}$. If spawning did not occur after $1 \mathrm{~h}$, sperm from male animals from the same site was collected by shucking the animal and manually removing sperm from the ripe gonads. The collected sperm was then added to the water in each table to stimulate spawning. Once a female began to spawn, it was immediately removed from the table to minimize mixing of eggs with other females' eggs, then placed in a small plastic cup with enough saltwater to cover the entire oyster. At first, an attempt was made to spawn individuals in cups rather than starting them on the table, but oysters did not respond to this method. Thus, the reported fecundity estimates are underestimates of the total amount of eggs released by each female, because some eggs had been released on the spawning table before females were placed in the cups. Individual cups were labeled and female oysters were left for a minimum of $1 \mathrm{~h}$ to finish spawning. Spawning males were identified, but they were left on the table to encourage female spawning.

\section{Oyster and egg processing}

Once spawning was complete, the saltwater-egg mixture from each individual cup was filtered through a 150-micron $(\mu \mathrm{m})$ screen to remove debris, and collected in a 30-liter bucket filled with seawater. A small sample of the diluted mixture was then placed on a slide and counted, using an Olympus BX41 compound microscope on the $4 \times$ objective 
Table 2

Microsatellite markers used in this study

\begin{tabular}{|c|c|c|c|c|c|c|}
\hline Locus & $\begin{array}{c}\text { Repeat } \\
\text { structure }\end{array}$ & $\begin{array}{c}\text { Primer sequence }\left(5^{\prime}-3^{\prime}\right) \\
(\mathrm{F}=\text { forward, } \mathrm{R}=\text { reverse })\end{array}$ & $\begin{array}{c}\mathrm{MgCl}_{2} \\
\left(\mathrm{mmol} \mathrm{l}^{-1}\right)\end{array}$ & $T_{a}\left({ }^{\circ} \mathrm{C}\right)$ & $\begin{array}{c}\mathrm{T} 3 \text { primer } \\
\text { fluorescent-label }\end{array}$ & Reference \\
\hline Cvilg8 & $(\mathrm{CT})_{16}$ & $\begin{array}{l}\text { F: GCTACACACGAAAAATGGG } \\
\text { R: TCAAATGAAGAGCACCTCC }\end{array}$ & 2.0 & 46.0 & VIC & Reece et al., 2004 \\
\hline CvisVIMS & $(\mathrm{CT})_{19}$ & $\begin{array}{l}\text { F: ATAAAAGTCCATTCGTAAGC } \\
\text { R: AGATTTGAAGTATTGCTATCG }\end{array}$ & 1.5 & 47.0 & PET & Carlsson et al., 2006 \\
\hline Cvi2g14 & $(\mathrm{TC})_{4} \mathrm{TT}(\mathrm{TC})_{20}$ & $\begin{array}{l}\text { F: GTCCTAACTACATTTATCACAC } \\
\text { R: TTCTTCTTACAAAACAGACTG }\end{array}$ & 1.5 & 59.0 & VIC & Reece et al., 2004 \\
\hline CviGISb4 & $(\mathrm{GA})_{25}$ & $\begin{array}{l}\text { F: G CGG AGA CGA GAC AGA CTC } \\
\text { R: AGG CTA TCC CAA CCA CCT C }\end{array}$ & 1.5 & 56.7 & 6-FAM2 & $\begin{array}{l}\text { J. E. Carlsson and K. S. Reece, } \\
\text { (unpubl. data) }\end{array}$ \\
\hline
\end{tabular}

$\mathrm{MgCl}_{2}$, magnesium chloride concentration for the polymerase chain reaction (PCR); $T_{a}$, annealing temperature for PCR.

(Olympus America, Inc., Melville, NY). Egg counts represent the total number of eggs, regardless of fertilization status. However, approximately $75 \%-90 \%$ of the eggs were fertilized as a result of spawning males that were left on the spawning tables (S. T. Alexander, pers. comm.). Counts were repeated at least 3 times, with additional counts carried out if values differed by more than $10 \%$. Spawned oysters were removed from individual cups, and shell height ( $\mathrm{mm}$ ), dry tissue weight (g), and Perkinsus marinus (dermo) infection intensity were determined for each female. Dermo weighted prevalence (scale of infection from $0-5$, where $0=$ no infection and $5=$ very heavy infection) was assessed, using the diagnostic methods of Ray (1952), because of the known correlation between dermo infection and reduced condition index and fecundity in oysters (Choi et al., 1989; Paynter, 1996). The remaining saltwater-egg mixture was then run through a $20-\mu \mathrm{m}$ sieve to concentrate the eggs in a small area. Eggs were removed from the sieve, using a glass pipette, and placed in a 20-ml centrifuge tube. Eggs were frozen and stored at $-20{ }^{\circ} \mathrm{C}$ in vials containing a nitrogen gas atmosphere, until lipid analysis, according to standard procedures (Budge et al., 2006).

\section{Genetic analysis}

To combat low natural recruitment, the University of Maryland Center for Environmental Science Horn Point Oyster Hatchery $(\mathrm{HPOH})$ in Cambridge, Maryland, has been providing Crassostrea virginica juveniles (spat-onshell) for seeding on oyster bars in Chesapeake Bay for over two decades. Thus, we knew the exact ages of oysters from locations that were seeded with hatchery-reared spat-onshell, including those used in this study. One concern with using adult oysters produced from hatchery-reared spat is genetic diversity and possible negative impacts on reproductive success (Hare et al., 2006). Therefore, the genetic relatedness of oysters from Year 2 was determined using DNA microsatellite amplification to distinguish potential patterns observed as a result of environment or oyster age from those associated with potential kinship.

For genetic analysis in 2011, a small (about $1 \mathrm{~cm}^{3}$ ) sample of wet gill tissue was removed from 30 successfully spawned oysters from each site, placed in a micro-Eppendorf tube with absolute ethanol, and sealed prior to shipment for analysis. DNA was prepared using a modified Chelex extraction method (Launey and Hedgecock, 2001). The fixed tissue was rinsed in distilled water to remove ethanol before $500 \mu \mathrm{l}$ of $10 \%$ chelating resin (Chelex; Bio-Rad, Richmond, CA) and $12 \mu \mathrm{l}$ of Proteinase $\mathrm{K}\left(20 \mathrm{mg} \mathrm{ml}^{-1}\right)$ were added to each sample. The mixture was heated at $60{ }^{\circ} \mathrm{C}$ for $1 \mathrm{~h}$ and boiled $\left(100{ }^{\circ} \mathrm{C}\right)$ for $15 \mathrm{~min}$. Samples were centrifuged at maximum speed $(14,000 \mathrm{rpm})$, and the supernatant was stored at $4{ }^{\circ} \mathrm{C}$ until used as template for polymerase chain reaction (PCR).

The following microsatellite markers were used (see Table 2): Cvi2g14, Cvi1g8 (Reece et al., 2004); Cvi5VIMS (Carlsson et al., 2006); and CviGISb4 (J. E. Carlsson and K. S. Reece, unpubl. data). For amplification of the loci, a T3 tail (AATTAACCCTCACTAAAGGG) was added to the $5^{\prime}$ end of the forward primers. Loci were amplified in 5- $\mu$ l reactions with 5-50-ng template DNA and Invitrogen (Life Technologies Corp., Grand Island, NY) reagents at a final concentration of $0.2 \mu \mathrm{g} / \mu \mathrm{l}$ BSA, $1 \times$ PCR buffer, 0.2 mmol $\mathrm{l}^{-1}$ dNTP mixture, $1.5-2 \mathrm{mmol} \mathrm{l}^{-1} \mathrm{MgCl}_{2}$ (see Table 2 for each locus concentration), $0.025 \mathrm{U}$ Platinum Taq polymerase, $0.025 \mu \mathrm{mol} \mathrm{l}^{-1}$ unlabeled forward primer with a T3 tail, $0.1 \mu \mathrm{mol} \mathrm{l}^{-1}$ reverse primer, and $0.1 \mu \mathrm{mol} \mathrm{l}^{-1}$ universal T3 tailed primer labeled with a fluorescent dye, as shown in Table 2.

Microsatellite amplification was carried out on MJ Research thermocyclers (MJ Research, Inc., Waltham, MA), using the following parameters: initial denaturation at $95^{\circ} \mathrm{C}$ for $4 \mathrm{~min}$, followed by 30 cycles of denaturation at $94^{\circ} \mathrm{C}$ for $1 \mathrm{~min}$, annealing for $1 \mathrm{~min}$ (see Table 2 for temperatures), extension at $72{ }^{\circ} \mathrm{C}$ for $1 \mathrm{~min}$, and a final extension at $72{ }^{\circ} \mathrm{C}$ for $10 \mathrm{~min}$. Allele sizes were resolved using a $3130 \times 1$ 
Genetic Analyzer (Applied Biosystems, Norwalk, CT). Allele size determinations were made using a GeneScan 500 LIZ size standard (Thermo Fisher Scientific, Waltham, MA) with the GeneMarker ver. 1.75 program (SoftGenetics LLC, State College, PA). The minimum detectable peak height was set at 100 arbitrary fluorescence units (FU), and all allele calls were verified by visual inspection.

\section{Egg total lipid content and fatty acid composition}

We chose to examine three metrics of reproductive output to provide a detailed picture of the overall quality of output from each oyster. The total number of eggs spawned by individual oysters has been frequently used (e.g., Barber et al., 1988; Kennedy et al., 1995) as a metric of the quality of reproductive output, and was therefore included in the study. Quantifying the total number of eggs spawned is not invasive or destructive to the animal, and involves less time and equipment than other measures of reproductive output, making it a common metric for quantifying fecundity. We also incorporated egg total lipid content (ETLC) as an index of egg quality, because the lipid-rich egg yolk is the primary energy source for a fertilized embryo and is critical in oyster larval survival and development (Gallager et al., 1986; Gallager and Mann, 1986; Helm et al., 1991). Finally, fatty acid composition data have been widely used in the ecological literature to understand the dietary components of marine animals (Watanabe, 1982; Bell et al., 1986; Sargent et al., 1987; Ahlgren et al., 1990). Considering the importance of certain fatty acids in embryonic development in bivalves (Whyte et al., 1990, 1991; Helm et al., 1991; Marty et al., 1992), the fatty acid signature (FAS) of eggs from the female oysters was used to assess differences in the quality of eggs by age and river.

Eggs from individual females were analyzed for total lipid content (\% wet weight) and fatty acid composition. Total lipid was extracted from oyster samples, using a modified Folch et al. (1957) chloroform:methanol extraction method, as described in Budge et al. (2002). Each frozen sample was thawed and centrifuged at $2000 \mathrm{rpm}$ for $10 \mathrm{~min}$ to separate any residual saltwater or protein from the egg mass. Each weighed egg sample (total amount of spawned eggs per individual) was placed in $9 \mathrm{ml}$ of 2:1 chloroform:methanol $0.01 \%$ butylated hydroxytoluene (BHT) at $4{ }^{\circ} \mathrm{C}$ for at least $48 \mathrm{~h}$ to ensure complete extraction of lipids. Additional solvent was used during the extraction stage to maintain the solvent: water ratios recommended by Budge et al. (2006). The solvent was evaporated under $\mathrm{N}_{2}$ gas such that only lipid remained. Lipid was re-suspended at $50 \mathrm{mg}$ of lipid/ml in hexane and stored under nitrogen gas at $-20{ }^{\circ} \mathrm{C}$. The mass of the extracted lipid sample was used to determine the percentage of the initial sample that was lipid, or the ETLC content.

For gas chromatography (GC) analysis, fatty acid butyl esters (FABE) were prepared from total lipid extracts to ensure that any short chains present would not be lost via volatilization (Koopman et al., 1996, 2003; appendix 5, Budge et al., 2006). Fatty acids were separated and analyzed by GC using a Varian capillary GC (3800) with a flame ionization detector (ID) in a fused silica column $(30 \times 0.25$ $\mathrm{mm}$ internal diameter) (Zebron ZB-FFAP; Phenomenex, Torrance, CA). Helium was used as the carrier gas, and the gas line was equipped with an oxygen and water scrubber. The following temperature program was used to separate fatty acids by carbon chain length: $65{ }^{\circ} \mathrm{C}$ for $2 \mathrm{~min}$, then hold at $165{ }^{\circ} \mathrm{C}$ for $0.40 \mathrm{~min}$ after ramping at $20^{\circ} \mathrm{C} \mathrm{min}-1$, hold at $215^{\circ} \mathrm{C}$ for $6.6 \mathrm{~min}$ after ramping at $2{ }^{\circ} \mathrm{C}^{-1}$, and hold at $250{ }^{\circ} \mathrm{C}$ for $5 \mathrm{~min}$ after ramping at $5{ }^{\circ} \mathrm{C}^{-1}$. Up to 50 different fatty acids were identified, following Iverson $e t$ al. $(1997,2002)$. Fatty acid peaks were identified based on two sets of standards, a standard suite of known fatty acids (Nu-Chek Prep, Inc., Elysian, MN), and, for the subset of peaks present in the commercially available standards, fatty acids were identified based upon peak identification performed on a Thermo Trace Ultra GC/Polaris Q MS (Thermo Fisher Scientific). Fatty acids were run on the gas chromatograph-mass spectrometer (GC-MS; courtesy S. Budge, Dalhousie University) using a similar column. Peaks were then integrated using appropriate response factors (Ackman, 1991) with the Galaxie Chromatography Data System (ver. 1.8.501.1; Agilent Technologies, Santa Clara, CA). Peak identification was manually confirmed for each run. Each fatty acid was described using the nomenclature $A: B n-X$, where $A$ is the number of carbon atoms, $B$ is the number of double bonds, and $X$ is the position of the double bond closest to the terminal methyl group.

\section{Statistical analyses}

Statistical analyses were conducted using SAS ver. 9.2 (SAS Institute, Cary, NC) and Plymouth Routines in Multivariate Ecological Research (PRIMER6; Primer-E Ltd., Ivybridge, UK) statistical software, with $\alpha=0.05$ as the significance level for each program. For all variables, data for 2010 and 2011 were initially examined separately and then also combined. Since the results of the combined data were not different from the individual years separately, the data are reported for each year separately to examine dynamics within each year. To account for any differences in female oyster size, the relative fecundity data were examined as number of eggs per gram of tissue (dry weight). Variation in relative fecundity (number of eggs per female), shell height $(\mathrm{mm})$, dry weight $(\mathrm{g})$, and ETLC by collection site were examined using Kruskal-Wallis rank tests, with Dunn's test for multiple comparisons if the overall test was significant. Nonparametric tests were used for large differences in sample and variance among sampling groups. The relationship between relative fecundity and ETLC was examined using linear regression, and is reported for both 
Table 3

Mean metrics ( \pm SE) for female oysters by site and year collected

\begin{tabular}{|c|c|c|c|c|c|c|c|}
\hline $\begin{array}{l}\text { Sampling } \\
\text { year }\end{array}$ & $\begin{array}{l}\text { Site } \\
\text { code }\end{array}$ & $n$ & $\begin{array}{l}\text { Shell height } \\
(\mathrm{mm})\end{array}$ & Dry weight $(\mathrm{g})$ & $\begin{array}{l}\text { Egg count/dry wt } \\
\left(\text { millions gram }{ }^{-1}\right)\end{array}$ & $\begin{array}{l}\text { Dermo } \\
\text { WP }\end{array}$ & $\%$ Lipid \\
\hline \multirow[t]{4}{*}{2010} & MY & 10 & $105.1^{\mathrm{b}} \pm 5.8$ & $1.4 \pm 0.2$ & $7.5^{\mathrm{b}} \pm 1.8$ & $0.2 \pm 0.1$ & $3.0^{\mathrm{b}} \pm 0.2$ \\
\hline & MO & 4 & $127.0^{\mathrm{a}} \pm 5.9$ & $2.2 \pm 0.3$ & $1.5^{\mathrm{a}} \pm 0.6$ & $1.0 \pm 0.7$ & $5.3^{\mathrm{a}} \pm 0.6$ \\
\hline & $\mathrm{CY}$ & 10 & $100.9^{\mathrm{b}} \pm 5.2$ & $1.4 \pm 0.3$ & $11.2^{\mathrm{b}} \pm 2.3$ & $0.3 \pm 0.2$ & $2.8^{\mathrm{b}} \pm 0.4$ \\
\hline & $\mathrm{CO}_{\mathrm{a}}$ & 8 & $92.1^{b} \pm 5.9$ & $1.8 \pm 0.2$ & $8.8^{\mathrm{b}} \pm 1.2$ & $0.3 \pm 0.1$ & $2.9^{\mathrm{b}} \pm 0.5$ \\
\hline \multirow[t]{4}{*}{2011} & $\mathrm{MY}^{\mathrm{a}}$ & 20 & $110.8^{\mathrm{b}} \pm 4.1$ & $2.0 \pm 0.2$ & $4.2^{\mathrm{b}} \pm 0.3$ & $0.3^{\mathrm{b}} \pm 0.1$ & $4.8 \pm 0.3$ \\
\hline & MO & 12 & $134.1^{\mathrm{a}} \pm 5.8$ & $2.7 \pm 0.3$ & $2.4^{\mathrm{a}} \pm 0.4$ & $1.1^{\mathrm{a}} \pm 0.3$ & $5.0 \pm 0.3$ \\
\hline & $\mathrm{CY}$ & 20 & $100.6^{\mathrm{b}} \pm 4.0$ & $1.9 \pm 0.2$ & $3.6^{\mathrm{a}, \mathrm{b}} \pm 0.4$ & $0.3^{\mathrm{b}} \pm 0.2$ & $5.2 \pm 0.3$ \\
\hline & $\mathrm{CO}_{\mathrm{b}}$ & 17 & $107.7^{\mathrm{b}} \pm 2.9$ & $2.2 \pm 0.1$ & $5.3^{\mathrm{b}} \pm 0.8$ & $0.4^{\mathrm{b}} \pm 0.2$ & $4.7 \pm 0.4$ \\
\hline
\end{tabular}

Significant differences $(P<0.05)$ across the four sites for each variable are calculated separately for each year, and are indicated by different letters $(\mathrm{a}$ or b).

Dermo WP, Perkinsus marinus weighted prevalence. C, Choptank River; M, Magothy River; O, old; Y, young; $\mathrm{CO}_{\mathrm{a}}$, Choptank old Year $1 ; \mathrm{CO}_{\mathrm{b}}$, Choptank old Year 2.

years combined to increase sample size and to illustrate the patterns more clearly. Chi-squared analysis was used to test for differences in weighted prevalence (scale of infection from $0-5$, where $0=$ no infection and $5=$ very heavy infection) of dermo (Perkinsus marinus) by collection site. For genetic analysis, inter- and intra-sample variation were examined based on multi-locus genotypes, using unbiased $F$-statistics (Weir and Cockerham, 1984) based on Fisher's exact test, and were calculated using GENEPOP ver. 3.4 (Raymond and Rousset, 1995).

Patterns in fatty acid signatures (FAS) by site (proportion of all fatty acids present in each individual) were examined using PRIMER 6 software (Clarke, 1993; Clarke and Warwick, 2001; Clarke and Gorley, 2006), rather than examining patterns in individual fatty acids, to obtain a complete picture of the fatty acid composition of the eggs. Fifty individual fatty acids were identified using gas chromatography analysis; however, our analysis of FAS included only the fatty acids found in concentrations greater than $1 \%$. The concentrations of these 18 fatty acids (i.e., 14:0, 16:0, 16: 1n-7, 17:0, 18:0, 18:1n-9, 18:1n-7, 18:2n-6, 18:3n-3, 18: 4n-3, 20:1n-11, 20:1n-7, 20:4n-6, 20:5n-3, 22:1n-11, 22: 5n-6, 22:5n-3, and 22:6n-3) were analyzed for differences in FAS by site in our model. Differences in the omega- 3 and omega-6 $(\omega 3 / \omega 6)$ fatty acids included in the overall model were determined by a separate model $(18: 2 n-6,18: 3 n-3$, $18: 4 n-3,20: 4 n-6,20: 5 n-3,22: 5 n-6,22: 5 n-3$, and 22:6n-3). If a certain fatty acid was not detected in a single individual, the concentration of that fatty acid was changed from 0 to $0.005 \%$ (Iverson et al., 2002). This value was chosen because it is below the minimum detectable level of the gas chromatograph $(0.01 \%)$, but is not so small that it would result in extreme outliers (Iverson et al., 2002).

Resemblance matrices of fatty acid concentrations were created based on Bray-Curtis dissimilarity. Nonmetric multidimensional scaling (MDS; 25 restarts, Kruskal scheme 1) analyses were conducted on the fatty acid profiles of all samples by year. Multidimensional scaling stress values range from 0 to 1 ; low stress values indicated high confidence in the model, and stress values less than 0.2 were assumed to adequately represent the relationships of the samples in the model (Clarke and Warwick, 2001). Analyses of similarities (ANOSIM; two-way, maximum permutations $=999$ ) were conducted on all samples by site to evaluate the impact of oyster age and river on overall and $\omega 3 / \omega 6$ FAS. Analyses of similarities global $R$-values range from 0 to 1 ; higher global $R$-values are more significant. One-way similarity percentages analysis (SIMPER; twoway, based on Bray-Curtis dissimilarity, cutoff percentage $=90$ ) was conducted if ANOSIM was significant, to determine which fatty acids contributed the most to the differences observed between rivers or ages.

\section{Results}

\section{Overall metrics: 2010}

In 2010, 32 individual female oysters successfully spawned, out of the 800 animals that were collected from the 4 river sites. There was no significant difference in dry weight or dermo weighted prevalence by collection site $(P>0.05$ for all comparisons; Table 3$)$. While no difference in dry weight was found by site, old oysters (11-y-old) from the Magothy River (MO) were significantly larger (by shell height) than oysters from all other sites $(P<0.05$ for all pairwise comparisons with MO). The MO oysters produced an average of 1.5 million eggs per gram of dry tissue, a number that was significantly less than the 11.2 million eggs per gram of dry tissue produced by young oysters (3-y-old) from the Choptank River (CY) $(P<0.05$, Table 3 ). While young oysters (4-y-old) from the Magothy River (MY) produced an average of 7.5 million eggs per gram of dry tissue, and old oysters (9-y-old) from the Choptank 
River $\left(\mathrm{CO}_{\mathrm{a}}\right)$ oysters produced an average of 8.8 million eggs per gram of dry tissue, both groups of eggs per gram of dry tissue were not significantly different from the number of eggs per gram of dry tissue produced by CY oysters in 2010 $(P>0.05$ for all comparisons, Table 3$)$. The mean egg total lipid content (ETLC) of eggs from MO oysters was 5.3\%, significantly higher than the ETLC of eggs from oysters from all other sites (i.e., MY: $3.0 \%$; $\mathrm{CY}: 2.8 \% ; \mathrm{CO}_{\mathrm{a}}: 2.9 \%$; $P<0.05$ for all pairwise comparisons with MO).

\section{Overall metrics: 2011}

A total of 64 individual female oysters successfully spawned, out of the 800 animals that were collected from the 4 sites in 2011 (Table 3). Similar to the 2010 oysters, no significant difference in dry weight was observed by collection site $(P>0.05)$ in 2011 , and MO oysters were significantly larger (by shell height) than oysters from all other sites $(P<0.05$ for all pairwise comparisons with MO). The MO oysters produced an average of 2.4 million eggs per gram of dry tissue, a significantly lower number than the 5.3 million eggs per gram of dry tissue produced by old oysters (9-y-old) from the Choptank River in $2011\left(\mathrm{CO}_{\mathrm{b}}\right)$ and the 4.2 million eggs per gram of dry tissue produced by MY individuals $(P<0.05$ for comparisons with $\mathrm{MO})$. The $\mathrm{CY}$ individuals produced an average of 3.6 million eggs per gram of dry tissue, which was not significantly different from the number of eggs per gram of dry tissue produced by oysters at any other site ( $P>0.05$ for all comparisons). The MO oysters displayed an average dermo weighted prevalence of 1.1 (on a scale of $0-5$ ), which was significantly greater than the average dermo weighted prevalence at all other sites (i.e., MY, 0.3; CY, 0.3; $\mathrm{CO}_{\mathrm{b}}, 0.4 ; P<0.05$ for all pairwise comparisons with MO). In contrast to the ETLC data for 2010, the average 2011 ETLC data did not vary significantly by site $(P>0.05)$; for all sites, the average ETLC was between $4.7 \%$ and $5.2 \%$ in 2011 .

\section{Egg total lipid content (ETLC) by egg count}

The data for both 2010 and 2011 were combined to examine the relationship between ETLC and the number of eggs per dry weight with maximum statistical power. These data were examined using linear regression, and showed a significant negative relationship between lipid content and number of eggs produced per gram of dry weight $(P=$ $0.002, R^{2}=0.10$ ).

\section{Genetic analysis}

Genetic analyses were conducted on all populations in 2011 to determine genetic relatedness among populations. Pairwise fixation indices $\left(F_{s t}\right)$ and $P$-values are shown in Table 4. All pairwise comparisons showed significant ge-
Table 4

$\mathrm{F}_{\mathrm{st}}$ (above dashed diagonal) and $\mathrm{P}$-values (below dashed diagonal) for all pairwise comparisons by population collected in 2011

\begin{tabular}{lcccr}
\hline \hline & MY & MO & CY & $C O_{b}$ \\
\hline MY & & & & \\
MO & $<0.001$ & & 0.0106 & $\mathbf{0 . 0 0 0 5}$ \\
$\mathrm{CY}$ & $<0.001$ & $<0.001$ & 0.0242 & 0.0204 \\
$\mathrm{CO}_{\mathbf{b}}$ & $\mathbf{0 . 1 1 2}$ & $<0.001$ & $<0.001$ & 0.0198 \\
\hline
\end{tabular}

Individuals analyzed for each site were MY: 20, MO: 12, CY: 20, CO : 17. The data indicate that all populations were significantly different genetically, except for the MY and $\mathrm{CO}_{\mathrm{b}}$ samples (in bold).

$F_{\text {st }}$, fixation index. C, Choptank River; M, Magothy River; O, old; Y, young; $\mathrm{CO}_{\mathrm{b}}$, Choptank River old Year 2.

netic differences $(P<0.001)$, except for the MY and $\mathrm{CO}_{\mathrm{b}}$ sample comparison $(P=0.11)$.

\section{Composition of egg fatty acids}

Although 50 individual fatty acids were identified using gas chromatography analysis, our model included only the 18 fatty acids found in concentrations greater than $1 \%$. The levels of these 18 different fatty acids constituted each sample's fatty acid signature (FAS), and were used to compare egg FAS by sampling years and sites (Table 5). In 2010, significant differences were found in the overall FAS of eggs by river $(P=0.001$, global $R=0.467$, 2-dimensional (2D) stress $=0.11$; Fig. 2a). SIMPER analysis indicated that percent concentrations of 16:0, 20:5n-3, and 22:6n-3 fatty acids, specifically, were the most influential in separating the fatty acid signatures between rivers. No significant differences were observed in the overall FAS of eggs by age in $2010(P>0.05$, global $R=0.216)$. As with the overall FAS data by river from 2010, significant differences were found in the $\omega 3 / \omega 6 \mathrm{FAS}$ of eggs by river in 2010 $(P=0.001$, global $R=0.359,2 \mathrm{D}$ stress $=0.10$; Fig. $2 \mathrm{~b})$. SIMPER analyses showed that the percent concentrations of 20:5n-3 and 22:6n-3 contributed to at least $63 \%$ of the variation observed in essential FAS by river in 2010. No significant differences were observed in the $\omega 3 / \omega 6$ FAS of eggs by age in $2010(P>0.05$, global $R=0.103)$. In 2011, when females from the 4 sites were moved to the same site before oogenesis, no significant differences were observed in overall or $\omega 3 / \omega 6$ fatty acid composition of oyster eggs by river or age $(P>0.05$ for both factors; global $R=0.054$ and 0.023 , respectively; 2D stress $=0.15$ and 0.09 , respectively; Fig. 3a, b).

\section{Discussion}

The goal of our study was to examine the influence of environment and ontogeny on the quantity and quality of the reproductive output of four restored oyster populations in 
Table 5

Sampling year, sample size, mean percent composition, and standard error of all fatty acids that were included in non-parametric models to analyze eastern oyster Crassostrea virginica eggs for patterns in fatty acid signatures

\begin{tabular}{|c|c|c|c|c|c|c|c|c|c|}
\hline$\underline{\text { Year }}$ & Site & $\mathrm{n}$ & $14: 0$ & $16: 0$ & $16: 1 n-7$ & 17:0 & 18:0 & $18: 1 n-9$ & $18: 1 n-7$ \\
\hline \multirow[t]{4}{*}{2010} & MY & 10 & $4.19 \pm 1.02$ & $25.06 \pm 2.45$ & $2.90 \pm 0.48$ & $1.92 \pm 0.40$ & $4.25 \pm 0.86$ & $4.64 \pm 0.33$ & $3.76 \pm 0.37$ \\
\hline & MO & 4 & $5.33 \pm 0.99$ & $27.13 \pm 0.23$ & $2.45 \pm 0.96$ & $1.54 \pm 0.21$ & $4.94 \pm 0.77$ & $4.89 \pm 0.70$ & $2.55 \pm 0.70$ \\
\hline & $\mathrm{CY}$ & 10 & $6.40 \pm 1.30$ & $24.75 \pm 2.27$ & $4.46 \pm 1.93$ & $1.52 \pm 0.31$ & $4.15 \pm 0.66$ & $3.48 \pm 0.69$ & $4.43 \pm 1.78$ \\
\hline & $\mathrm{CO}$ & 8 & $4.88 \pm 1.29$ & $25.84 \pm 1.43$ & $4.66 \pm 0.46$ & $1.36 \pm 0.16$ & $4.07 \pm 0.38$ & $4.25 \pm 0.34$ & $4.45 \pm 0.48$ \\
\hline \multirow[t]{4}{*}{2011} & MY & 20 & $3.52 \pm 1.13$ & $25.40 \pm 0.90$ & $2.21 \pm 0.49$ & $1.39 \pm 0.17$ & $4.39 \pm 0.36$ & $5.70 \pm 0.68$ & $2.90 \pm 0.79$ \\
\hline & MO & 12 & $3.01 \pm 0.85$ & $24.51 \pm 0.66$ & $1.73 \pm 0.53$ & $1.33 \pm 0.12$ & $4.51 \pm 0.33$ & $5.83 \pm 0.61$ & $2.92 \pm 0.33$ \\
\hline & $\mathrm{CY}$ & 20 & $3.15 \pm 0.91$ & $26.00 \pm 0.80$ & $1.91 \pm 0.52$ & $1.41 \pm 0.16$ & $4.39 \pm 0.48$ & $5.71 \pm 0.75$ & $2.64 \pm 0.95$ \\
\hline & $\mathrm{CO}$ & 17 & $3.14 \pm 0.89$ & $25.12 \pm 1.01$ & $2.15 \pm 0.51$ & $1.42 \pm 0.14$ & $4.37 \pm 0.46$ & $5.76 \pm 0.74$ & $3.04 \pm 0.39$ \\
\hline Year & Site & & $8: 2 n-6$ & $18: 3 n-3$ & $18: 4 n-3$ & $20: 1 \mathrm{n}-11$ & $20: 1 \mathrm{n}-7$ & $20: 4 n-6$ & $20: 5 n-3$ \\
\hline \multirow[t]{4}{*}{2010} & MY & & $2 \pm 0.25$ & $3.24 \pm 0.62$ & $3.02 \pm 0.51$ & $1.86 \pm 0.34$ & $3.00 \pm 0.26$ & $1.56 \pm 0.24$ & $8.38 \pm 0.97$ \\
\hline & MO & & $5 \pm 0.20$ & $3.22 \pm 0.40$ & $4.39 \pm 0.59$ & $1.97 \pm 0.17$ & $2.64 \pm 0.53$ & $1.26 \pm 0.14$ & $8.17 \pm 0.88$ \\
\hline & $\mathrm{CY}$ & & $0 \pm 0.27$ & $3.24 \pm 0.67$ & $3.08 \pm 0.67$ & $1.69 \pm 0.49$ & $3.87 \pm 0.77$ & $1.08 \pm 0.20$ & $9.11 \pm 1.26$ \\
\hline & $\mathrm{CO}$ & & $6 \pm 0.15$ & $4.59 \pm 0.57$ & $3.61 \pm 0.36$ & $1.58 \pm 0.33$ & $2.92 \pm 0.42$ & $1.06 \pm 0.15$ & $9.52 \pm 0.71$ \\
\hline \multirow[t]{4}{*}{2011} & MY & & $7 \pm 0.31$ & $4.41 \pm 0.89$ & $4.57 \pm 0.67$ & $0.49 \pm 0.09$ & $2.94 \pm 0.41$ & $2.22 \pm 0.63$ & $9.66 \pm 0.99$ \\
\hline & MO & & $3 \pm 0.26$ & $5.13 \pm 0.69$ & $4.92 \pm 0.35$ & $0.55 \pm 0.09$ & $3.12 \pm 0.33$ & $2.20 \pm 0.43$ & $9.71 \pm 0.97$ \\
\hline & $\mathrm{CY}$ & & $9 \pm 0.29$ & $4.83 \pm 0.80$ & $4.85 \pm 0.63$ & $0.50 \pm 0.11$ & $2.95 \pm 0.30$ & $1.60 \pm 0.24$ & $10.31 \pm 0.96$ \\
\hline & $\mathrm{CO}$ & & $5 \pm 0.30$ & $4.78 \pm 0.89$ & $4.76 \pm 0.58$ & $0.52 \pm 0.10$ & $3.03 \pm 0.40$ & $1.67 \pm 0.27$ & $10.69 \pm 1.35$ \\
\hline Year & Site & & $22: 1 n-11$ & $22: 5 n-6$ & $22: 5 n-3$ & $22: 6 n-$ & Sum & Sum n6 & $\mathrm{n} 3: \mathrm{n} 6$ \\
\hline \multirow[t]{4}{*}{2010} & MY & & $2.40 \pm 0.28$ & $0.59 \pm 0.11$ & $0.23 \pm 0.15$ & $11.54 \pm 2$ & 2.43 & 4.27 & 6.18 \\
\hline & MO & & $1.86 \pm 0.24$ & $0.35 \pm 0.20$ & $0.15 \pm 0.05$ & $11.94 \pm 2$ & 2.16 & 4.05 & 6.94 \\
\hline & $\mathrm{CY}$ & & $1.91 \pm 0.80$ & $0.38 \pm 0.07$ & $0.22 \pm 0.12$ & $8.50 \pm 2$ & 2.20 & 3.15 & 7.67 \\
\hline & $\mathrm{CO}$ & & $2.07 \pm 0.43$ & $0.48 \pm 0.09$ & $0.15 \pm 0.08$ & $8.98 \pm 1$ & 1.67 & 3.70 & 7.26 \\
\hline \multirow[t]{4}{*}{2011} & MY & & $2.31 \pm 0.35$ & $0.50 \pm 0.23$ & $0.88 \pm 0.10$ & $13.86 \pm$ & 1.05 & 5.79 & 5.80 \\
\hline & MO & & $2.35 \pm 0.33$ & $0.50 \pm 0.16$ & $0.87 \pm 0.05$ & $13.24 \pm$ & 1.17 & 5.74 & 5.92 \\
\hline & $\mathrm{CY}$ & & $2.30 \pm 0.18$ & $0.56 \pm 0.07$ & $0.94 \pm 0.05$ & $13.75 \pm 1$ & 1.13 & 5.14 & 6.75 \\
\hline & $\mathrm{CO}$ & & $2.31 \pm 0.52$ & $0.57 \pm 0.09$ & $0.95 \pm 0.08$ & $13.53 \pm 1$ & 1.11 & 5.19 & 6.70 \\
\hline
\end{tabular}

Means for all omega-3 $(\omega 3)$ and omega-6 ( $\omega 6)$ fatty acids, and the ratio of omega-3 to omega-6 fatty acids in the model are also shown. C, Choptank River; M, Magothy River; O, old; Y, young.

Chesapeake Bay. We achieved this goal by collecting, over two years, eggs from female oysters of two known ages, from two different rivers with previously determined differences in phytoplankton composition in Chesapeake Bay. We quantified the number of eggs per gram of dried tissue of individual female oysters from these populations, and determined the quality of the eggs produced by lipid content and fatty acid signature analyses. In Year 1, oysters underwent oogenesis at their respective collection sites, enabling them to incorporate possible environmental differences into their reproductive output. During Year 2, oysters were collected from the four different sites in the fall and moved to a single location for the winter, forcing them all to undergo oogenesis in the same location.

While quantifying the phytoplankton composition in the two rivers was outside the scope of this study, we obtained data on their phytoplankton composition from the Chesapeake Bay Program (2013) and isotopic signature $\left(\delta^{15} \mathrm{~N}\right)$ data (Fertig et al., 2010). The phytoplankton data indicated that oysters that underwent oogenesis in two different rivers in
Year 1 of this study likely experienced different food sources, both in phytoplankton abundance and species diversity (Chesapeake Bay Program, 2013). Therefore, when the oysters underwent oogenesis in the same river during Year 2 of this study, the difference in food source was likely eliminated.

In addition to known differences in environment and food composition, the age of all oysters in this study was known, a rarity in studies of wild bivalve populations. For example, the lack of natural oyster recruitment in the northern portion of Chesapeake Bay, combined with a well-documented hatchery seeding program conducted for the past two decades by the Horn Point Oyster Hatchery (HPOH) in this same area, made it possible to confidently determine the age of the oysters in our study. These known differences in environment (and, likely, food source) and knowledge of oysters' age allowed us to assess with confidence the impact of both on the physiology of oysters in Chesapeake Bay, as quantified by changes in quantity and quality of eggs.

The data from our study show that environment was a primary driver of the quality (fatty acid signature (FAS), in 

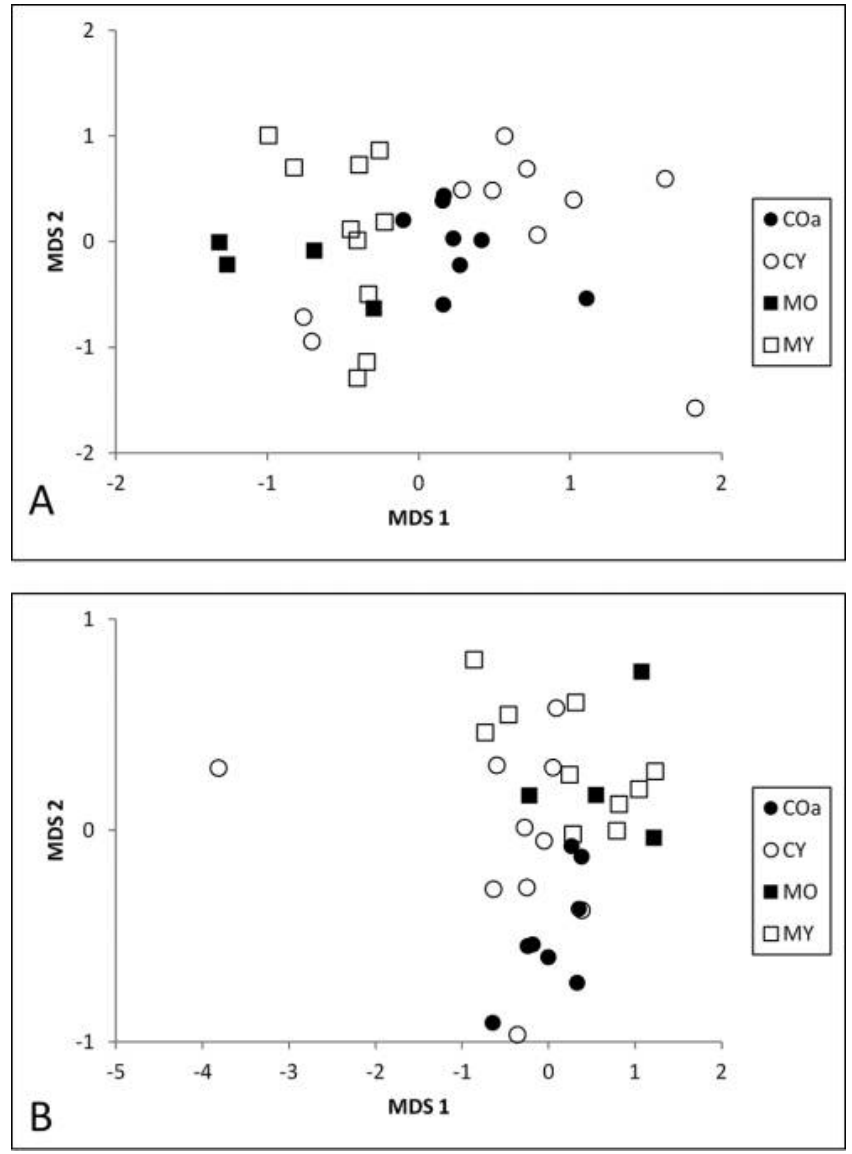

Figure 2. (A) Multidimensional scaling (MDS) plot of the overall fatty acid signatures (FAS) of eggs by site in 2010. Analysis of similarities (ANOSIM) showed significant differences in FAS of eggs by river $(P=$ 0.001 , global $R=0.467$, two-dimensional (2D) stress $=0.11$ ). Similarity percentages analysis (SIMPER) showed that percent concentrations of $16: 0,29: 5 n-3$, and 22:6n-3 fatty acids, specifically, were the most influential in separating the FAS between rivers. No significant differences were seen in the overall FAS by age of oyster in 2010. (B) MDS plot of the essential FAS of eggs by site in 2010. ANOSIM showed significant differences in essential FAS of eggs by $\operatorname{river}(P=0.001$; global $R=0.359$; $2 \mathrm{D}$ stress $=0.10)$. SIMPER analyses showed that the percent concentrations of $20: 5 n-3$ and $22: 6 n-3$ contributed to at least $63 \%$ of the variation seen in essential FAS by river in 2010. No significant differences were noted in the $\omega 3 / \omega 6$ FAS of eggs by age of oyster in 2010 . One young oyster from the Choptank River (CY) was suspected of being an outlier, but was retained in the model because trends were similar whether it was included or excluded. There was no experimental basis for removing the individual. $\mathrm{CO}_{\mathrm{a}}$, Choptank River old Year 1; CY, Choptank River young; MO, Magothy River; MO, Magothy River old; MY, Magothy River young; MDS 1, multidimensional scaling axis 1; MDS 2, multidimensional scaling axis 2 .

this study) of oyster eggs, and that oyster age at the time of spawning was less important in influencing egg quality. In our study, FAS (overall and $\omega 3 / \omega 6$ ) from oysters that underwent oogenesis in different rivers also differed significantly. Oyster age, on the other hand, was not a driver of differences observed in the overall or $\omega 3 / \omega 6$ egg FAS during Year 1. However, in Year 2, when oysters underwent
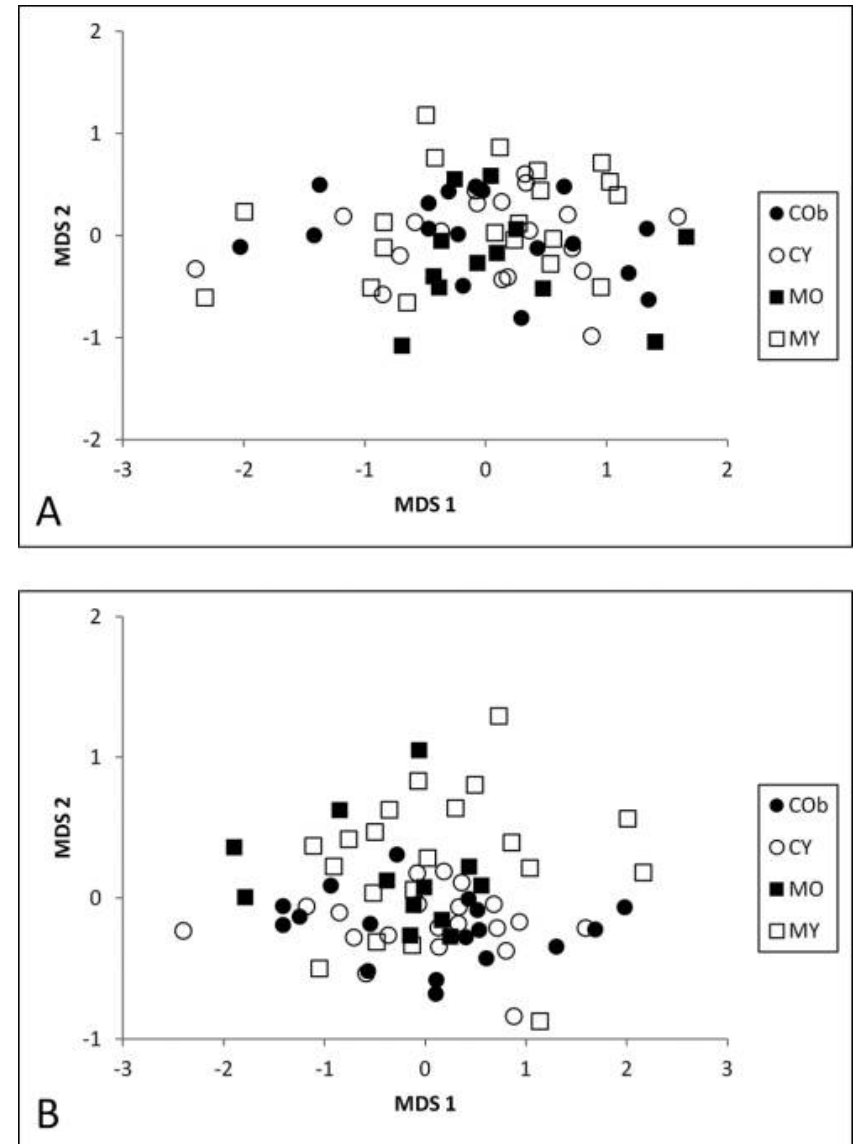

Figure 3. (A) Multidimensional scaling (MDS) plot of the overall fatty acid signatures (FAS) of eggs by collection site in 2011. Analysis of similarities (ANOSIM) showed no significant differences in the overall FAS of eggs by river or age $(P>0.05$, global $R=0.054,2 \mathrm{D}$ stress $=$ 0.15). (B) MDS plot of the essential FAS of eggs by collection site in 2011. ANOSIM revealed no significant differences in essential FAS of eggs by river or age $(P>0.05$, global $R=0.023,2 \mathrm{D}$ stress $=0.09) . \mathrm{CO}_{\mathrm{b}}$, Choptank River old Year 2; CY, Choptank River young; MO, Magothy River old; MY, Magothy River young; MDS 1, multidimensional scaling axis 1; MDS 2, multidimensional scaling axis 2 .

oogenesis at the same location, no significant differences in the overall or $\omega 3 / \omega 6$ egg FAS were observed in the populations sampled. These data underscore the importance of environment during oogenesis in influencing FAS of the eggs of oysters, and have implications for spatial variability in the quality of eggs in the Chesapeake Bay oyster population.

While the patterns observed in the egg FAS of oysters in this study are compelling, the relative fecundity (number of eggs per gram of dried tissue) and egg total lipid content (ETLC) were also examined to provide a complete picture of the reproductive output. These data suggest a significant negative relationship between ETLC and the number of eggs per gram of dry tissue. However, the $R^{2}$ value of this relationship was very low (0.10), and was likely driven by a few individuals that produced a large number of eggs, an 
indicator that egg count was not a reliable predictor for ETLC over the range of egg count per gram of dry tissue in this study. However, data from old oysters from the Magothy River (MO) oysters in 2010 suggest there may be a fixed amount of lipid resources which female oysters can allocate to egg production. The MO oysters produced nearly $75 \%$ fewer eggs than did oysters from all the other sites, and yet those (MO) eggs contained significantly more lipid than did eggs from the other sites in $2010(P>0.05)$. Still, the low number of individuals that produced a very high number of eggs (greater than 10 million eggs per gram of dried tissue) in this study limits the applicability of these trends to other populations.

Every adult female included in this study displayed a low level of Perkinsus marinus (dermo) infection. High infection prevalence paired with low infection intensity is common for adult oysters in northern Chesapeake Bay (Burreson and Calvo, 1996). Dermo infection can have sublethal effects on adult oysters, such as reducing fecundity (Choi et al., 1989; Paynter, 1996). However, dermo infection levels observed in animals in our study were below levels expected to impact fecundity. Although the MO oysters collected in 2011 had significantly higher levels of dermo infection than did oysters from the other sites, the weighted prevalence of 1.1 (on a scale from 0 to 5) observed in these animals was well below the level of concern for sublethal infections.

The primary finding of our study was the impact of environment on egg FAS of oysters. Changes in diet impact the FAS of individuals in many marine species (Kirsch et al., 1998; Raclot et al., 1998; Iverson et al., 2004), but data on the impact of parental diet on reproductive outputs remain limited. We chose to examine the FAS of eggs rather than the FAS of adult oysters themselves to understand the impact of parental diet and age on reproductive output. This technique has proven effective in characterizing the benthic food web (Kelly and Scheibling, 2012), and has been used to determine the impact of parental diet on egg lipid content and FAS in black-lip pearl oysters Pinctada margaritifera (Ehteshami et al., 2011), identify trophic pathways in bearded seals Erignathus barbatus and Pacific walruses Odobenus rosmarus (Budge et al., 2007), and examine patterns in the milk of Antarctic fur seals Arctocephalus gazelle (Brown et al., 1999).

Our study found significant differences in the overall and $\omega 3 / \omega 6$ egg FAS of animals by river in 2010 (see Fig. 2a, b). While analysis of similarities (ANOSIM) is known to be sensitive to small sample sizes and differences in dispersion, we found differences in egg FAS across all sites in 2010, not just the site with the lowest sample size (2010 MO; $n=4)$. Further analyses indicated that no significant differences were observed in relation to the duration of an animal's exposure to a given site (based on its age). However, no difference in the overall or $\omega 3 / \omega 6$ egg FAS was observed by river in 2011 (see Fig. 3a, b), when oogenesis occurred in the same location. Since all population combinations except MY and $\mathrm{CO}_{\mathrm{b}}$ were genetically distinct in 2011 (see Table 3 ), these data suggest that oyster diet, rather than genetic relatedness through resampling of the same population, has a significant effect on the fatty acid signatures of the eggs those oysters produce. The possibility that the similarity in the FAS observed in the 2011 individuals would have been present regardless of oogenesis location cannot be overlooked, since individuals that completed oogenesis in the original locations were not sampled during that year.

The importance of specific fatty acids to normal development early in life has been explored in the literature (Wainwright et al., 1992; Sargent et al., 1997, 1999). Based on those studies, we did not expect to see a significant effect of the female's diet on the FAS of her eggs. The findings of this study call into question the idea that the FAS of eggs is constrained solely by the requirements of the developing embryo, and underscore the impact of environment on the quality of reproductive outputs. Since salinity and temperature were similar at all sites during both years of this study, environmental differences reflect potential differences in phytoplankton composition between the two rivers examined. The results of our study indicate that differences in location of oogenesis can be reflected in oyster egg FAS, and that these diet differences overwhelm any consistent FAS present in all oyster eggs.

Certain fatty acids (20:5n-3 and 22:6n-3) are necessary for oyster egg and larval development (Whyte et al., 1990, 1991; Helm et al., 1991; Marty et al., 1992), but what is not known is how flexible the proportions of these fatty acids are in each individual. The concept of a minimum threshold percentage of certain $\omega 3 / \omega 6$ fatty acids has been explored in many bivalve species, particularly as it relates to larval development (e.g., Caers et al., 2002; Hendriks et al., 2003; Milke et al., 2004), and may also be at work in this system. Our data showed that the concentrations of $20: 5 n-3$ and 22:6n-3 fatty acids contributed significantly to the variation in egg FAS by site in 2010, suggesting influences of environment on egg and larval development in our system. However, the observed differences in fatty acid concentrations of 20:5n-3 and 22:6n-3 in 2010 may be above minimum thresholds for essential fatty acids in all populations, and may not significantly impact the development of these eggs into the larval stage and beyond. Understanding the role of specific fatty acids in the quality of oyster embryos and larvae in the Chesapeake Bay population is important in the context of the impact of geospatial location (and variability in phytoplankton community composition) on oyster survival in this system.

Our study aimed to quantify the impact of age and geospatial location on the quality of eggs from oysters 
collected from two locations in Chesapeake Bay with significantly different food availability. Considering the observational nature of our work, a controlled-diet study is necessary to definitively quantify the impact of specific fatty acids on the FAS of oyster eggs. Embryonic and larval conditions have been linked to adult survival and fecundity in a variety of bivalve species (Gallager et al., 1986; Caers et al., 2002; Milke et al., 2004). Therefore, quantifying the effects of the differences observed in egg FAS on other measures of reproductive success, such as fertilization success, larval survival, and/or settlement success will place the findings of this study in the greater context of oyster survival and ecosystem impact. Determining the effects of these differences in biochemical composition on oyster survival will not only prove valuable to understanding the impacts of environment and ontogeny on reproductive physiology of oysters and other similar species, but may also provide practical techniques for improving the efficiency of hatchery production through the targeted creation of highquality eggs.

\section{Acknowledgments}

We would like to thank K. Kesler, S. Lombardi, D. Needham, R. Kulp, G. Chon, and J. Luke, as well as the staff at the HPOH for experimental help. We would also like to thank T. J. Miller for statistical support. This is contribution No. 5256 of the University of Maryland Center for Environmental Science Horn Point Laboratory, and contribution No. 3592 of the Virginia Institute of Marine Science. This manuscript was greatly improved by suggestions from two anonymous reviewers. This study was funded through a grant from the Oyster Recovery Partnership in Annapolis, Maryland.

\section{Literature Cited}

Ackman, R. G. 1991. Application of gas-liquid chromatography to lipid separation and analysis: qualitative and quantitative analysis. Pp. 271300 in Analysis of Fats, Oils and Lipoproteins, E. G. Perkins, ed. American Oil Chemists' Society, Champaign, IL.

Ahlgren, G., L. Lundstedt, M. Brett, and C. Forsberg. 1990. Lipid composition and food quality of some freshwater phytoplankton for cladoceran zooplankters. J. Plankton Res. 12: 809-818.

Andrewartha, H. G., and L. C. Birch. 1954. The Distribution and Abundance of Animals. University of Chicago Press, Chicago.

Barber, B. J., S. E. Ford, and H. H. Haskin. 1988. Effects of the parasite MSX (Haplosporidium nelsoni) on oyster (Crassostrea virginica) energy metabolism. I. Condition index and relative fecundity. $J$. Shellfish Res. 7: 25-31.

Bell, G. 1984. Evolutionary and nonevolutionary theories of senescence. Am. Nat. 124: 600-603.

Bell, M. V., R. J. Henderson, and J. R. Sargent. 1986. The role of polyunsaturated fatty acids in fish. Comp. Biochem. Physiol. B Comp. Biochem. 83: 711-719.

Brown, D. J., I. L. Boyd, G. C. Cripps, and P. J. Butler. 1999. Fatty acid signature analysis from the milk of Antarctic fur seals and southern elephant seals from South Georgia: implications for diet determination. Mar. Ecol. Prog. Ser. 187: 251-263.
Brown, J. H., J. F. Gillooly, A. P. Allen, V. M. Savage, and G. B. West. 2004. Toward a metabolic theory of ecology. Ecology 85: 17711789.

Budge, S. M., S. J. Iverson, W. D. Bowen, and R. G. Ackman. 2002. Among- and within-species variability in fatty acid signatures of marine fish and invertebrates on the Scotian Shelf, Georges Bank, and southern Gulf of St. Lawrence. Can. J. Fish. Aquat. Sci. 59: 886-898.

Budge, S. M., S. J. Iverson, and H. N. Koopman. 2006. Studying trophic ecology in marine ecosystems using fatty acids: a primer on analysis and interpretation. Mar. Mammal Sci. 22: 759-801.

Budge, S. M., A. M. Springer, S. J. Iverson, and G. Sheffield. 2007. Fatty acid biomarkers reveal niche separation in an Arctic benthic food web. Mar. Ecol. Prog. Ser. 336: 305-309.

Burreson, E. M., and L. M. R. Calvo. 1996. Epizootiology of Perkinsus marinus disease of oysters in Chesapeake Bay, with emphasis on data since 1985. J. Shellfish Res. 15: 17-34.

Caers, M., S. D. Utting, P. Coutteau, P. F. Millican, and P. Sorgeloos. 2002. Impact of the supplementation of a docosahexaenoic acid-rich emulsion on the reproductive output of oyster broodstock, Crassostrea gigas. Mar. Biol. 140: 1157-1166.

Carlsson, J., C. L. Morrison, and K. S. Reece. 2006. Wild and aquaculture populations of the eastern oyster compared using microsatellites. J. Hered. 97: 595-598.

Chesapeake Bay Program. 2013. Baywide CBP Plankton Database 1984-present. Chesapeake Bay Program, Annapolis, MD. Available: http://www.chesapeakebay.net/data/downloads/baywide_cbp_plankton_ database [2013, Nov. 21].

Choi, K.-S., E. A. Wilson, D. H. Lewis, E. N. Powell, and S. M. Ray. 1989. The energetic cost of Perkinsus marinus parasitism in oysters: quantification of the thioglycollate method. J. Shellfish Res. 8: 125131.

Choi, K.-S., D. H. Lewis, E. N. Powell, and S. M. Ray. 1993. Quantitative measurement of reproductive output in the American oyster, Crassostrea virginica (Gmelin), using an enzyme-linked immunosorbent assay (ELISA). Aquac. Res. 24: 299-322.

Chown, S. L., and K. J. Gaston. 2008. Macrophysiology for a changing world. Proc. R. Soc. B Biol. Sci. 275: 1469-1478.

Clarke, K. R. 1993. Non-parametric multivariate analyses of changes in community structure. Austral Ecol. 18: 117-143.

Clarke, K. R., and R. N. Gorley. 2006. PRIMER v6: User Manual/ Tutorial. PRIMER-E, Plymouth, UK. 192 p.

Clarke, K. R., and R. M. Warwick. 2001. Change in Marine Communities: an Approach to Statistical Analysis and Interpretation, 2nd ed., PRIMER-E, Plymouth, UK. 172 p.

Cox, C., and R. Mann. 1992. Temporal and spatial changes in fecundity of eastern oysters, Crassostrea virginica (Gmelin, 1791) in the lower James River, Virginia. J. Shellfish Res. 11: 49-54.

Dahlhoff, E. P., J. H. Stillman, and B. A. Menge. 2002. Physiological community ecology: variation in metabolic activity of ecologically important rocky intertidal invertebrates along environmental gradients. Integr. Comp. Biol. 42: 862-871.

Dayton, P. K. 1971. Competition, disturbance, and community organization: the provision and subsequent utilization of space in a rocky intertidal community. Ecol. Monogr. 41: 351-389.

Deslous-Paoli, J.-M., and M. Heral. 1988. Biochemical composition and energy value of Crassostrea gigas (Thunberg) cultured in the bay of Marennes-Oleron. Aquat. Living Resour. 1: 239-249.

Ehteshami, F., A. Christianus, H. Rameshi, S. A. Harmin, and C. R. Saad. 2011. The effects of dietary supplements of polyunsaturated fatty acid on pearl oyster, Pinctada margaritifera L., gonad composition and reproductive output. Aquac. Res. 42: 613-622.

Enriquez-Diaz, M. R. 2004. Reproduction variability and bionergetics in the Pacific oyster, Crassostrea gigas. Ph.D. dissertation, Université de Bretagne Occidentale, Brest, France. 
Fertig, B., T. J. B. Carruthers, W. C. Dennison, E. J. Fertig, and M. A. Altabet. 2010. Eastern oyster (Crassostrea virginica) $\delta^{15} \mathrm{~N}$ as a bioindicator of nitrogen sources: observations and modeling. Mar. Pollut. Bull. 60: 1288-1298.

Folch, J., M. Lees, and G. H. Sloane Stanley. 1957. A simple method for the isolation and purification of total lipids from animal tissues. J. Biol. Chem. 226: 497-509.

Gallager, S. M., and R. Mann. 1986. Growth and survival of Mercenaria mercenaria (L.) and Crassostrea virginica (Gmelin) relative to broodstock conditioning and lipid content of eggs. Aquaculture 56: 105-121.

Gallager, S. M., R. Mann, and G. C. Sasaki. 1986. Lipid as an index of growth and viability in three species of bivalve larvae. Aquaculture 56: $81-103$.

Grabowski, J. H., and C. H. Peterson. 2007. Restoring oyster reefs to recover ecosystem services. Pp. 281-298 in Ecosystem Engineers: Concepts, Theory and Applications, K. Cuddington, J. E. Byers, W. G. Wilson, and A. Hastings, eds. Amsterdam.

Hare, M. P., S. K. Allen, Jr., P. Bloomer, M. D. Camara, R. B. Carnegie, J. Murfree, M. Luckenbach, D. Meritt, C. Morrison, K. T. Paynter et al. 2006. A genetic test for recruitment enhancement in Chesapeake Bay oysters, Crassostrea virginica, after population supplementation with a disease tolerant strain. Conserv. Genet. 7: 717-734.

Helm, M. M., D. L. Holland, S. D. Utting, and J. East. 1991. Fatty acid composition of early non-feeding larvae of the European flat oyster, Ostrea edulis. J. Mar. Biol. Assoc. U.K. 71: 691-705.

Hendriks, I. E., L. A. van Duren, and P. M. J. Herman. 2003. Effect of dietary polyunsaturated fatty acids on reproductive output and larval growth of bivalves. J. Exp. Mar. Biol. Ecol. 296: 199-213.

Hofmann, E. E., E. N. Powell, J. M. Klinck, and E. A. Wilson. 1992. Modeling oyster populations III. Critical feeding periods, growth and reproduction. J. Shellfish Res. 11: 399-416.

Iverson, S. J., K. J. Frost, and L. F. Lowry. 1997. Fatty acid signatures reveal fine scale structure of foraging distribution of harbor seals and their prey in Prince William Sound, Alaska. Mar. Ecol. Prog. Ser. 151: 255-271.

Iverson, S. J., K. J. Frost, and S. L. C. Lang. 2002. Fat content and fatty acid composition of forage fish and invertebrates in Prince William Sound, Alaska: factors contributing to among and within species variability. Mar. Ecol. Prog. Ser. 241: 161-181.

Iverson, S. J., C. Field, W. D. Bowen, and W. Blanchard. 2004. Quantitative fatty acid signature analysis: a new method of estimating predator diets. Ecol. Monogr. 74: 211-235.

Kang, S.-G., K.-S. Choi, A. A. Bulgakov, Y. Kim, and S.-Y. Kim. 2003. Enzyme-linked immunosorbent assay (ELISA) used in quantification of reproductive output in the pacific oyster, Crassostrea gigas, in Korea. J. Exp. Mar. Biol. Ecol. 282: 1-21.

Kearney, M., and W. Porter. 2009. Mechanistic niche modelling: combining physiological and spatial data to predict species' ranges. Ecol. Lett. 12: 334-350.

Kelly, J. R., and R. E. Scheibling. 2012. Fatty acids as dietary tracers in benthic food webs. Mar. Ecol. Prog. Ser. 446: 1-22.

Kennedy, V. S. 1996. Biology of larvae and spat. Pp 371-421 in The Eastern Oyster, Crassostrea virginica, V. S. Kennedy, R. I. E. Newell, and A. F. Eble, eds. 1996. University of Maryland Sea Grant College, College Park, MD.

Kennedy, V. S., R. I. E. Newell, G. E. Krantz, and S. Otto. 1995. Reproductive capacity of the eastern oyster Crassostrea virginica infected with the parasite Perkinsus marinus. Dis. Aquat. Org. 23: $135-144$.

Kirsch, P. E., S. J. Iverson, W. D. Bowen, S. R. Kerr, and R. G. Ackman. 1998. Dietary effects on the fatty acid signature of whole Atlantic cod (Gadus morhua). Can. J. Fish. Aquat. Sci. 55: 1378-1386.
Koopman, H. N., S. J. Iverson, and D. E. Gaskin. 1996. Stratification and age-related differences in blubber fatty acids of the male harbour porpoise (Phococena phocoena). J. Comp. Phvsiol. B. 165: 628-639.

Koopman, H. N., S. J. Iverson, and A. J. Read. 2003. High concentrations of isovaleric acid in the fats of odontocetes: variation and patterns of accumulation in blubber vs. stability in the melon. J. Comp. Phvsiol. B. 173: 247-261.

Launey, S., and D. Hedgecock. 2001. High genetic load in the Pacific oyster Crassostrea gigas. Genetics 159: 255-265.

Lewis, J. R. 1964. The Ecology of Rocky Shores. English Universities Press, London.

Marty, Y., F. Delaunay, J. Moal, and J.-F. Samain. 1992. Changes in the fatty acid composition of Pecten maximus (L.) during larval development. J. Exp. Mar. Biol. Ecol. 163: 221-234.

Milke, L. M., V. M. Bricelj, and C. C. Parrish. 2004. Growth of postlarval sea scallops, Placopecten magellanicus, on microalgal diets, with emphasis on the nutritional role of lipids and fatty acids. Aquaculture 234: 293-317.

Newell, R. I. E., and S. J. Jordan. 1983. Preferential ingestion of organic material by the American oyster Crassostrea virginica. Mar. Ecol. Prog. Ser. 13: 47-53.

Newell, R. I. E., T. R. Fisher, R. R. Holyoke, and J. C. Cornwell. 2003. Influence of eastern oysters on nitrogen and phosphorus regeneration in Chesapeake Bay, USA. Pp. 93-120 in The Comparative Roles of Suspension-Feeders in Ecosystems, R. F. Dame and S. Olenin, eds. Springer, Dordrecht, the Netherlands.

Paynter, K. T. 1996. The effects of Perkinsus marinus infection on physiological processes in the eastern oyster, Crassostrea virginica. J. Shellfish Res. 15: 119-125.

Peterson, C. H., J. H. Grabowski, and S. P. Powers. 2003. Estimated enhancement of fish production resulting from restoring oyster reef habitat: quantitative valuation. Mar. Ecol. Prog. Ser. 264: 249-264.

Philipp, E. E. R., and D. Abele. 2010. Masters of longevity: lessons from long-lived bivalves-a mini-review. Gerontology 56: 55-65.

Phillips, N. E. 2007. High variability in egg size and energetic content among intertidal mussels. Biol. Bull. 212: 12-19.

Porter, E. T., J. C. Cornwell, and L. P. Sanford. 2004. Effects of oysters Crassostrea virginica and bottom shear velocity on benthicpelagic coupling and estuarine water quality. Mar. Ecol. Prog. Ser. 271: $61-75$.

Porter, W. P., J. L. Sabo, C. R. Tracy, O. J. Reichman, and N. Ramankutty. 2002. Physiology on a landscape scale: plant-animal interactions. Integ. Comp. Biol. 42: 431-453.

Powell, E. N., E. E. Hofmann, J. M. Klinck, and S. M. Ray. 1992. Modeling oyster populations I. A commentary on filtration rate. Is faster always better? J. Shellfish Res. 11: 387-398.

Promislow, D. E. L. 1991. Senescence in natural populations of mammals: a comparative study. Evolution 45: 1869-1887.

Raclot, T., R. Groscolas, and Y. Cherel. 1998. Fatty acid evidence for the importance of myctophid fishes in the diet of king penguins, Aptenodytes patagonicus. Mar. Biol. 132: 523-533.

Ray, S. M. 1952. A culture technique for the diagnosis of infections with Dermocystidium marinum Mackin, Owen and Collier in oysters. Science 116: $360-361$.

Raymond, M., and F. Rousset. 1995. GENEPOP (version 1.2): population genetics software for exact tests and ecumenicism. J. Hered. 86: $248-249$.

Reece, K. S., W. L. Ribeiro, P. M. Gaffney, R. B. Carnegie, and S. K. Allen, Jr. 2004. Microsatellite marker development and analysis in the eastern oyster (Crassostrea virginica): confirmation of null alleles and non-Mendelian segregation ratios. J. Hered. 95: 346-352.

Rodney, W. S., and K. T. Paynter. 2006. Comparisons of macrofaunal assemblages on restored and non-restored oyster reefs in mesohaline 
regions of Chesapeake Bay in Maryland. J. Exp. Mar. Biol. Ecol. 335: $39-51$.

Royer, J., C. Seguineau, K.-I. Park, S. Pouvreau, K.-S. Choi, and K. Costil. 2008. Gametogenetic cycle and reproductive effort assessed by two methods in 3 age classes of Pacific oysters, Crassostrea gigas, reared in Normandy. Aquaculture 277: 313-320.

Sargent, J., L. A. McEvoy, and J. G. Bell. 1997. Requirements, presentation and sources of polyunsaturated fatty acids in marine fish larval feeds. Aquaculture 155: 117-127.

Sargent, J., G. Bell, L. McEvoy, D. Tocher, and A. Estevez. 1999. Recent developments in the essential fatty acid nutrition of fish. Aquaculture 177: 191-199.

Sargent, J. R., R. J. Parkes, I. Mueller-Harvey, and R. J. Henderson. 1987. Lipid biomarkers in marine ecology. Pp. 119-138 in Microbes in the Sea, Ellis Horwood Series in Marine Science, M. A. Sleigh, ed. Ellis Horwoods, Chichester, U.K.

Thompson, R. J., R. I. E. Newell, V. S. Kennedy, and R. Mann. 1996.
Reproductive processes and early development. Pp. 335-370 in The Eastern Oyster, V. S. Kennedy, R. I. E. Newell, and A. F. Eble, eds. University of Maryland Sea Grant College, College Park, MD.

Wainwright, P. E., Y. S. Huang, B. Bulman-Fleming, D. E. Mills, P. Redden, and D. McCutcheon. 1992. The effects of dietary n-3/n-6 ratio on brain development in the mouse: a dose response study with long-chain n-3 fatty acids. Lipids 27: 98-103.

Watanabe, T. 1982. Lipid nutrition in fish. Comp. Biochem. Physiol. B Comp. Biochem. 73: 3-15.

Weir, B. S., and C. C. Cockerham. 1984. Estimating $F$-statistics for the analysis of population structure. Evolution 38: 1358-1370.

Whyte, J. N. C., N. Bourne, and N. G. Ginther. 1990. Biochemical and energy changes during embryogenesis in the rock scallop Crassadoma gigantea. Mar. Biol. 106: 239-244.

Whyte, J. N. C., N. Bourne, and N. G. Ginther. 1991. Depletion of nutrient reserves during embryogenesis in the scallop Patinopecten yessoensis (Jay). J. Exp. Mar. Biol. Ecol. 149: 67-79. 